UDC: $332.6(4)$

DOI: $10.14438 /$ gn.2014.05

\title{
Review of existing land funds in European countries
}

\author{
Dragana MILIĆEVIĆ ${ }^{1 *}$
}

${ }^{1}$ University of Belgrade, Faculty of Civil engineering, Belgrade, Serbia

\begin{abstract}
Land funds are very important instrument for regulation of land and rural development. The first land funds in European countries were founded in mid-nineteenth century. The importance of land funds in procedures of land regulation, improving of agricultural production and creating the conditions for the development of rural areas was recognized during $\mathrm{XX}$ century. During this period in the majority of European countries land funds/land banks were established. Land funds in the European countries vary significantly according to model, organization, management and financing. This paper will show the basic characteristics of some land funds in some of the European countries.
\end{abstract}

Keywords: land funds, land banks, land management, land development, rural development 


\section{Introduction}

The need for increased food production is caused by rapid increase of world population. For comparison, at the beginning of 2006 world population was about 6.5 billion, while in 2011 the number exceeded 7 billion. The increase of population leads to the expansion of urban areas at the expense of farming land. Also it causes increasingly negative effect on the environment which reflects on the scope of food production and its quality.

Land is a limited resource and it is becoming more and more limited with the expansion of urban zones and the environmental pollution. Accordingly, the need emerges to use it in the most effective way enabling maximum production and minimal consequences to the environment. Advancement of agricultural production can be enabled through introduction of measures from the domain of food production technologies: growing high yealding cultures, using various types of fertilizers, controlled protection from pests and numerous others. Apart from this, it will also be necessary to change the structure of land plots by merging the parcels, optimizing the shape and form of parcels, building infrastructural systems and other. One of the most frequently applied measures for consolidating land parcels in European countries during the 20th century was land consolidation.

If land consolidation is observed as a system, than the components of the modern land consolidation system include cadastres, land funds, land evaluation and land market [23]. Depending on the tradition, habits and interest of the state, the number of components can be higher or lower, but the synchronization of all subsystems represents a theoretical or minimal requirement for successful implementation of the land consolidation program.

In order for the land consolidation to be done successfully and to create increased number of possibility for merging land plots, many countries resorted to forming the so-called land funds/land banks. Land funds can be defined as land reserves that are formed with the objective of improving the structure of agricultural land and easier implementation of the land development projects [2].

First land funds were established with the objective of providing support to implementation of land consolidation projects. Therefore these funds included only agricultural land. Subsequently some countries included forest and urban land in these funds as well.

In the USA the concept of land banking was developed for the purpose of solving the problem of empty or vacant urban land and objects. The development of the industry in the US and the midwest lead to migration of population to the suburbs and to the abandonment of land and houses. All these vacant houses represent a threat to safety and an environment for development of crime. Therefore the concept of land banking is an attempt to solve these problems.

The objectives of establishing land funds in different countries mostly overlap - land consolidation, land regulation, land augmentation. However, individual objectives are the reflection of the heritage and land management policies and can greatly differ.

Republic of Serbia doesn't have an institionally regulated land fund, but it does have government owned land that is managed by the ministry in charge of agriculture. The need for establishing a land fund in Serbia will become bigger in time. The development of large infrastructural objects and implementation of restitution will significantly deteriorate the structure of land plots and the need for regulating this area will grow. Therefore, positive experiences of European countries can be applied and land funds can be used as instruments for regulating land.

\section{Literature review}

Experts that dealt with land regulation in western European countries realized the significance of land funds for successful implementation of land consolidation projects at the end of the 19th and early 20th century. Ever since then the land funds have become the irreplaceable instruments for consolidating agricultural land. On the other hand, in some European countries by the end of the 20th century they never moved past the idea of their creation. The reasons for this were in the traditional way of land management, agricultural relations, economic reasons or the lack of interest. Over the last decade this issue become very important. In order to promote the importance of land funds, UN FAO (Food and Agricultural Organization of the United Nations) organized numerous meetings to discuss this topic. The objective of these meetings were to present the experiences of different countries in establishing and managing land funds as well as to give 
guidelines for their utilization outside the land consolidation projects.

The first international meeting called „International Workshop on Land Banking / Land Funds as an Instrument for Improved Land Management in CEEC and CIS“ [15] was held in Tonder, Denmark in 2004. This gathering brought together a high number of international experts that presented types of land consolidation and objectives of establishing land funds in different states.

Regional FAO office for Europe and Central Asia organized international meetings in Prague (,Land Banks and Impact Assessment"[16]), Santiago de Composteli 2009 („Land Development Instruments and Information Tools to Assist Land Structure Reforms: the Galician Experience"[14]), Prague 2010 („Land Banking and Public Land Management”[18]), Budapest 2010 („International Workshop on Land Consolidation and Land Banking“[17]) and Budapest 2012 („International Workshop on Land Markets and Land consolidation"[19]). In these meetings models of land funds were presented as well as progress in their functioning in individual countries. The result of these international conferences was a publication called "Land Banks and Land Funds, Instruments for Rural Development", the draft of which is currently in the reviewing phase.

After the end of WWII the former Socialist Federal Republic of Yugoslavia passed the legislation that enabled the seizure of private assets on various grounds. By seizing land, a fund of 1.566.000 ha was created, out of which 769.000 ha was assigned to government owned farms [5]. Agricultural land, both that owned by the government and that privately owned, was pulverized and plots were scattered. Also, road infrastructure was not developed and water supply and drainage was not properly done. This situation disabled the application of modern techniques and technologies, which lead to the need for implementing measures for consolidating land territory. The most frequently applied measures were regrouping (rounding up land owned by the government) and land consolidation. Land consolidation was frequently applied because as a method it provides solutions to various problems: enlargement of land, building of infrastructure, surveying, regulating legal property relations, etc.

The Republic of Serbia inherited the structure of land properties and problems in land management from its legal predecessors. With the adoption of the Law on Restitution of Property in 2011, a step forward was made towards returning the property to their former owners and their descendants. With the return of the property the ownership structure will be additionally compromised and it will be necessary to introduce the land consolidation measures.

Milicevic and others (2013) [24] point out the formation of land funds as an important recommendation for further development of land consolidation in the Republic of Serbia, together with finding ways to preserve deserted land and inclusion of national agricultural land into economy.

Migrations and withering away of population in some parts of Serbia are the reasons why more and more land remains unfarmed. The example of Spanish province Galicia shows that the land funds have proven to be the most effective instruments in combating deserted land [9]. Through formation of land funds and change of management policies of agricultural land, the deserted land can be brought to use in the interest of the state and title holders over such land.

Argument that justifies the formation of land funds in the Republic of Serbia is the small size of land parcels and the necessity to implement the land consolidation projects. Land consolidation in the Republic of Serbia has to date been implemented at about $25 \%$ of the teritorry [1] and is an absolute necessity for any future advancement of agricultural production.

\section{Land funds}

\subsection{What is land fund?}

Land fund is a mechanism that enables the acquiring, management and disposal of land in rural areas with the aim of improving the agricultural production. One of the definitions that best describes the land fund was given by Damen in 2004:

"Land banking is the structural acquisition and temporary management of land in rural areas by an impartial State agency, with the purpose to redistribute and/or lease out this land with a view to improve the agricultural structure and/or to relocate the land for other purposes with a general public interest" [7].

Land funds in the European countries can differ 
in the following aspects:

- Objectives that should be achieved,

- Models,

- Organization and

- Financing.

These differences are the consequence of the inherited practice in managing agricultural land and the objectives of the government, local selfgovernment and individuals in terms of agricultural and rural development.

\subsection{Goals of land funds}

Although the oldest ones were formed with the view to give support to the land consolidation projects, it qickly became evident that land funds could be used for other purposes as well.

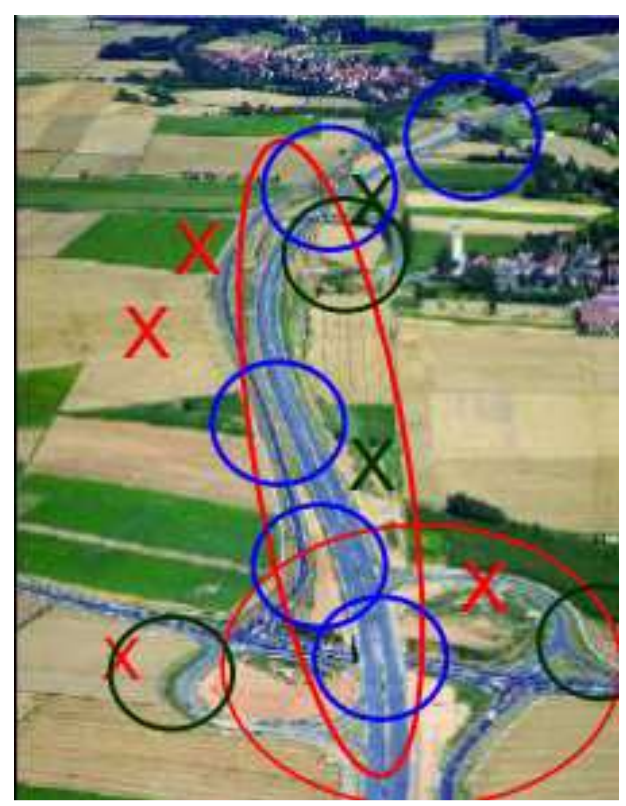

Figure 1. Problem with the development of infrastructural projects that can be solved with the use of land from land fund [26]
Nowadays land funds are used as an efficient instrument for the following:

- Support for land consolidation,

- Support to land market and its control,

- Support to land management,

- Support to implementation of projects of rural and urban development and infrastructural projects (Figure 1) [23].

The oldest land funds in Europe are in the Netherlands (1841. [7]) and Denmark (1921. [2]). Although they were formed primarily for the purposes of land consolidation in time they started to be used for other purposes as well.

The former socialist countries only saw the formation of land funds in the last decade of the 20th century. They were mostly comprised of government owned agricultural land. The objectives of their establishment were to implement the restitution and create conditions for enlargement of land property due to significant fragmentation.

\subsection{Land fund models}

The main difference between the land funds of the European countries is in whether the ownership of the land changes once it is included in the fund. The first land funds in Europe were formed from the government land and in time were expanded by purchasing land from farmers or other ways defined by the legislation [23] (Figure 2). This model is the model with the change of title (ownership) and is present in almost all countries that have land funds: Czech Republic, Hungary, Germany, Belgium, Netherlands...

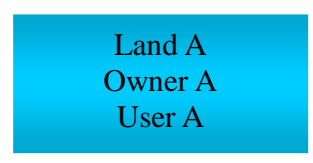

Old - Previous Situation

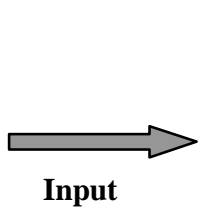

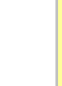

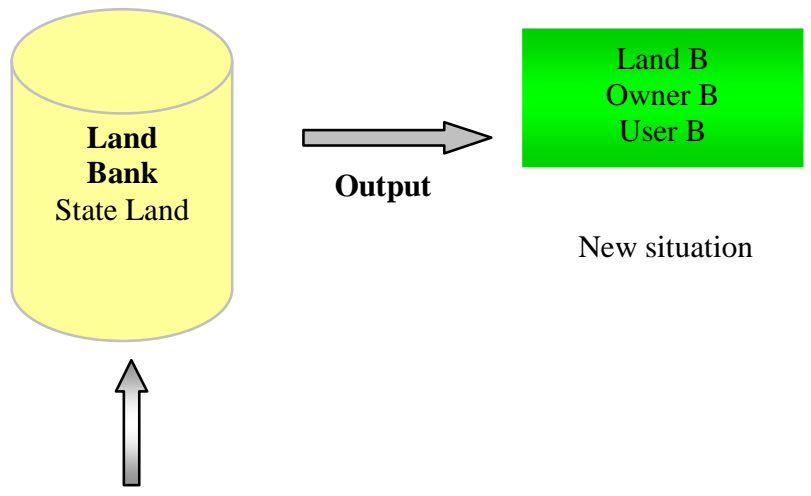

Management

Figure 2. Model of land fund with the change of title (ownership) [23]

The other model of land funds is the model

without the change of ownership structure over 
land. This model is not widely represented in Europe. Spanish province of Galicia has a land fund called BanTeGal (Banco de Terras de Galizis) that functions on the principle that the land owners remain owners even after the land becomes part of the land fund (Figure 3).

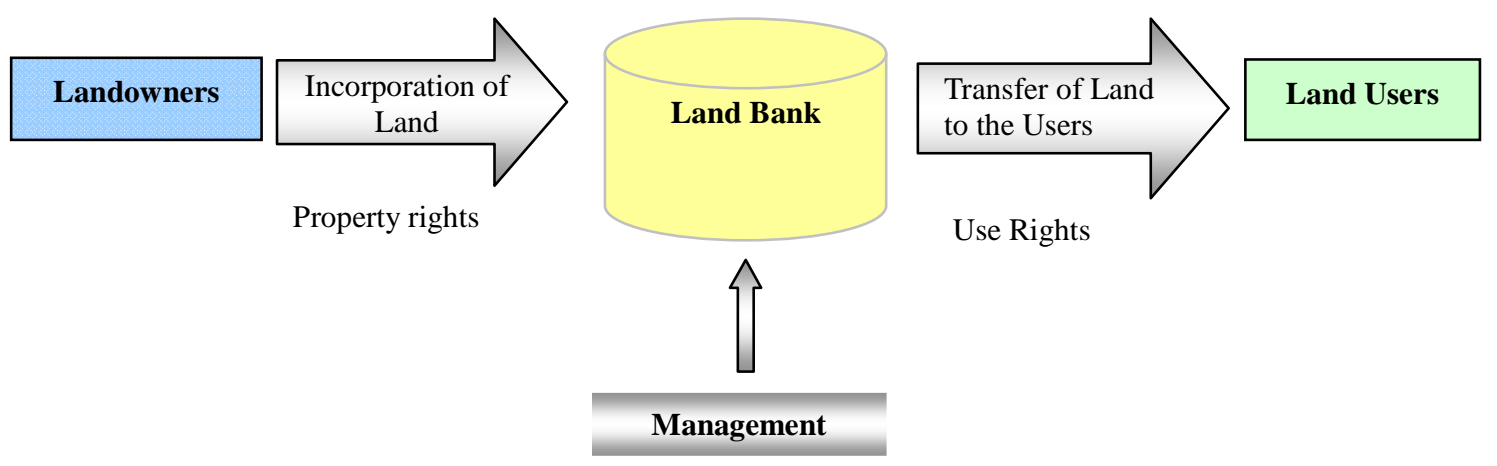

Figure 3. Model of land fund without the change of title holder (ownership) [23]

This model of land fund is extremely flexible and applicable to different geographic areas and different traditional models for land management both in governmental and private ownership.

\subsection{Organization of land funds}

Land funds are differently organized in different countries. In most countries they are organized as state institutions and function within relevant ministries (most commonly ministries in charge of agriculture or finance).

Organizational structure of land funds mostly consists of two levels. The first level is the level of the government and at that level the management function is assigned. The other level is the local level which mostly has the operational role. Most countries that have land funds (Netherlands, Sweden, Croatia, Hungary, Czech Republic, etc.) have this type of organizational structure.

The exceptions from this organizational structure are the land fund in Hungary National Land Foundation Management Organization (NLFMO) and the land fund of Galicia (Ban Te $\mathrm{Gal}$ ), which are organized at three levels. NLFMO is organized in such a way that there are 19 regional units that work with the local level of the land fund (cantonal services) [25]. BanTeGal is organized in a way that it has 4 regional offices which are the link between the central office and local offices [8].

It is specific for Holland that it has two land funds which function within different ministries. Apart from the fact that they were created in almost one century apart, these funds also differ in the roles they are assigned. The reason for having two land funds comes from different goals that were set before government bodies when they were constituted.

\subsection{Financing of land funds}

Fourth characteristic that differentiates the land funds in the European countries is how they are financed. There are two ways of financing them:

- Budget financing,

- Financing from own funds.

All land funds except for those in Galicia and Germany are governmental organization whose work is financed from the government budget.

Land funds in Galicia (BanTeGal) and Germany (BVVG) are organized as shareholding companies and are financed from own income.

Through sale and lease of land significant financial funds are acquired. With governmental land funds, these incomes are transferred to the government budget.

In the German BVVG fund they use part of the income to fund its work and the rest is transferred to the budget [22].

Land fund BanTeGal finances its activities from own funds, and the rest of the funds are distributed to land owners.

\section{Review of existing land funds}

Land funds exist in almost all European countries. They were initially organized in countries that had the need to preserve and protect their agricultural land (Denmark, Holland). In other countries they were established for easier implementation of land management and consolidation policies.

In this chapter we will present the land funds in 
five European countries: Denmark, Germany, Netherlands, Czech Republic and Galicia (Spain). Land funds in other countries are more or less similar. The characteristics that make the land funds in said countries specific are as follows:

- Denmark. Land fund in Denmark is one of the oldest in Europe. It is an example of efficient use of government land both in land consolidation and other projects in rural areas [4], [2].

- Germany. Land fund in Eastern Germany was founded in the last decade of the $20^{\text {th }}$ century for the purpose of restitution. Subsequently it became the federal agency for privatization. It is an example of shareholding company (although governmental organization) and it is an important factor in the real-estate market [22].

- Netherlands. In Holland there are two land funds under the auspices of two ministries. Holland is an example of careful planning of use and protection of land for the purpose of increasing efficiency of agricultural production [7].

- Czech Republic. Czech land fund was established in the last decade of the $20^{\text {th }}$ century with the same objective as in many other former socialist countries. Czech Republic is an example of inefficient land fund management and drastic reduction of agricultural land reserves owned by the government [20].

- Galicia (Spain). Spanish province Galicia has one of the youngest land funds in Europe. Its main characteristic was that it was organized as a shareholding company and it applies the model that doesn't require the change of land ownership structure [23]. It was formed primarily for the purpose of saving the deserted land and increase of agricultural production [13].

This chapter will present the most important characteristics of land funds in these countries: objectives of their creation, legislative grounds, organization and financing.

\subsection{Denmark}

Development of land funds in Denmark was conditioned with the change of agricultural relations from the end of the $18^{\text {th }}$ to mid $19^{\text {th }}$ century. In 1781 the principle of common property was abolished because farmers became interested in farming their own land [2]. In 1849 they adopted the Danish Privatization Act which supported the creation of independent farming in government or church land.

In 1921 the farmers were given the right to buy land under market conditions and to increase individual land plots through land funds. It is important to mention year 1941 when the Land Consolidation Act was adopted which was applied to the entire country. Adoption of this law significantly reinforced the role of land funds in land consolidation.

Since 1995 the land funds have been used as instruments of intervention in rural areas: in road construction, forestry, swamp draining etc. Over the last several years they have been increasingly used in water protection programs (,The Water Environmental Protection Program") [2].

Figure 4 shows the "movement" of land within the land fund in Denmark. For the purpose of realization of a project, the government would buy private land and include it into the land fund. The land can "come out" of the land fund both as private or public. Both ownership types over the land can be achieved as the result of land consolidation or implementation of a pre-planned project. The land which after "coming out" of the land fund remains public property is the land intended for development of infrastructural projects or projects intended for urban or rural development.

Use of land funds in Denmark has numerous advantages as well as shortcomings.

Advantages of use of land funds in Denmark are as follows:

- Reduction of costs for public interventions,

- Solving of land use disputes,

- Increase of number of voluntary land related agreements,

- They are required for conducting land consolidation [4]. 


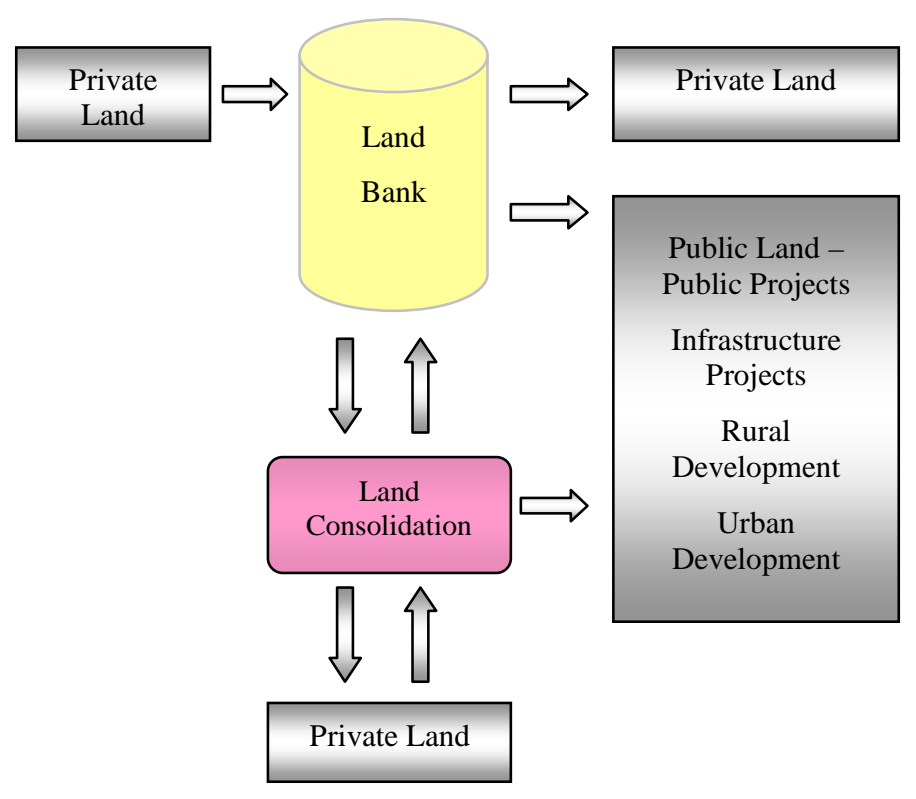

Figure 4. Movement of land within a land fund [4], [2], [23]

Use of land funds in Denmark also has its shortcomings [4]:

- Government appears as just another participant in the real estate market,

- How to prevent corruption,

- Does the government buy and sell land according to market prices,

- Land can be bought for specific projects without those projects ever actually being implemented.

Financing of activities of the land fund in Denmark is done from the government budget.

\subsection{Germany}

Land fund in Eastern Germany Bodenverwertungs-und-verwaltungs $\mathrm{GmbH}$ BVVG is a government company seated in Berlin. Main task of the land fund in Germany is balanced rural development.

BVVG was founded in 1992 under the auspices of the Ministry of Finance for the purpose of achieving two important goals:

- Privatization of agricultural and forest land owned by the government and

- Restitution.

Reasons that lead to the establishment of BVVG land fund were because by 1989:

- In East Germany almost $100 \%$ of agricultural land was government owned,

- Agrar structure was comprised of collective and large governmental farms,

- Land markets almost didn't exist [22].

In 1989 measures started to be implemented that enabled the development of agriculture: privatized farms were transformed, ownership of land was transformed and new structure of farms was developed.

Instruments that enabled the formation and efficient functioning of the BVVG land fund are:

- Coherent legislative framework,

- Land information system (multi-use cadastre),

- Simplified procedures for land transactions,

- Monitoring of independent market institutions,

- Implementation of spatial planning regulation,

- Efficient use of government agricultural land,

- Land valuation procedures,

- Subsidies programs for farmers [22].

Management structure of the BVVG land fund is such that the management is centralized while the operative structure is decentralized.

Work of BVVG is regulated by numerous legislative acts:

- BGB (German Civil Code),

- GrdstVG (Real Property Transactions Act), 
- GBO (Land Register Code),

- LPachtVG (Land Lease Transactions Act),

- Laws conc. Preservation of Nature, Forest Laws

- BauGB (Federal Building Act),
- Reichssiedlungsgesetz (Empire Settlement Act).

Today BVVG is an important stakeholder in the land market in Germany. Figure 5 shows the printscreen of the home page of BVVG website.

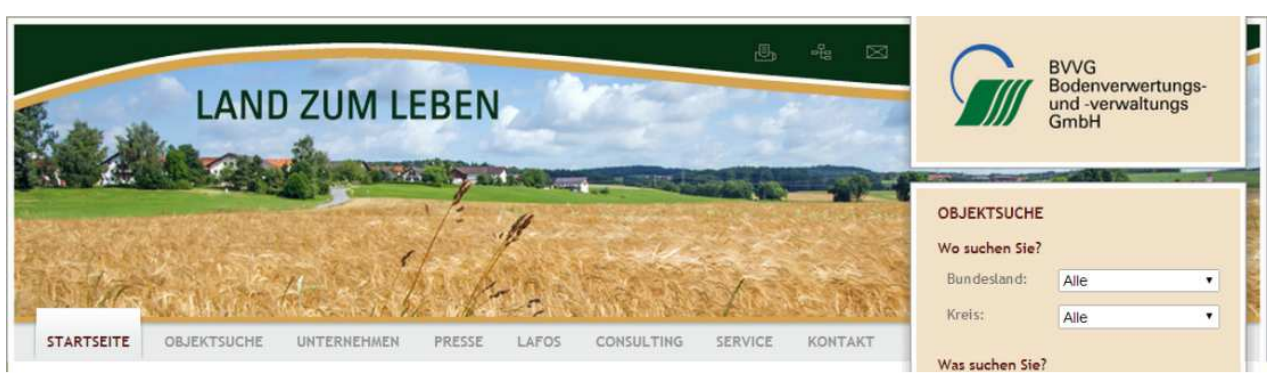

Figure 5. Printscreen of the home page of BVVG land fund website [21]

According to Kreese (2004) [22], currently around $70 \%$ of transactions in the land market are done through BVVG land fund. Fig. 6 shows comparative view of land sold in land market and that sold through BVVG land fund. Depending on the type of real estate, the share of land sold through BVVG fund ranges from $45 \%$ to $72 \%$ of the total land sold in the land market.
The most important characteristic of BVVG fund is its transparency. According to the model that had already been in use in West Germany, Valuation Boards were established in the East Germany as well. Their role was defined by the provisions of the Building Code of 1960, and among other their task is to develop maps of orientation values of real estate according to transactions done.

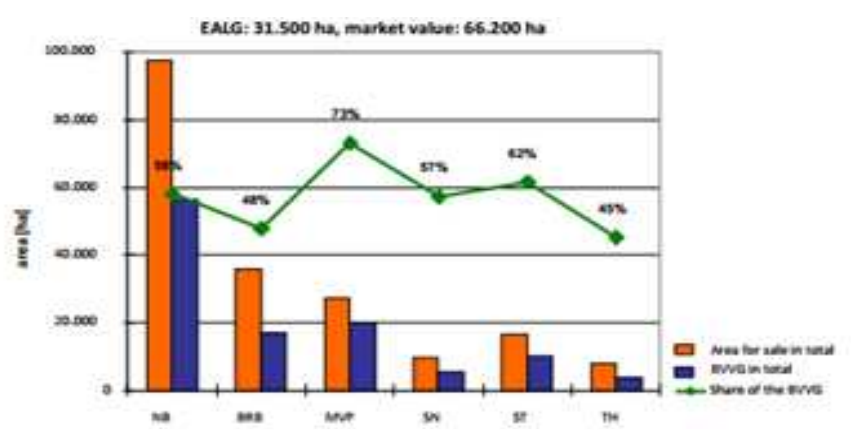

Figure 6. Surface area of land sold in the real estate market and through BVVG land fund [22]

The income made from lease and sale of realestate, the BVVG uses for financing its activities, while the rest of the money is transferred to the government budget.

\subsection{Netherlands}

Development of land funds in Holland was greatly conditioned by the acquiring agricultural land through desiccation. There were three stages in acquiring land and its development:

- In the period 1930 to 1970 about 175.000 ha of agricultural land was obtained through desiccation of the sea,

- During 50-ies and 60-ies efforts were invested into "improving" the land and bringing it to use,

- From 1960 onwards the Government supported the restructuring of farms for the purpose of achieving higher production efficiency [7].

In Holland there are currently two land funds. One of them is the State Domains Service (Domeinen) which was founded in 1841 within the Ministry of Finance. Today this fund manages the agricultural land area of 80.000 ha [7], with following tasks:

- Development of government land policies,

- Management of government owned land,

- Sale of government land.

Management of this land fund is decentralized with regional offices all around the country.

The first half of the $20^{\text {th }}$ century saw the establishment of another government land management agency - Wieringermeer or as it was 
later called Service of IJssellake Polders (RIJP). This agency was established within the Ministry of Transport and Water with the purpose of managing the "new" land, i.e. desiccated land. Figure 7 shows the largest artificial lake in the world which was managed by this agency in the phase of its development.

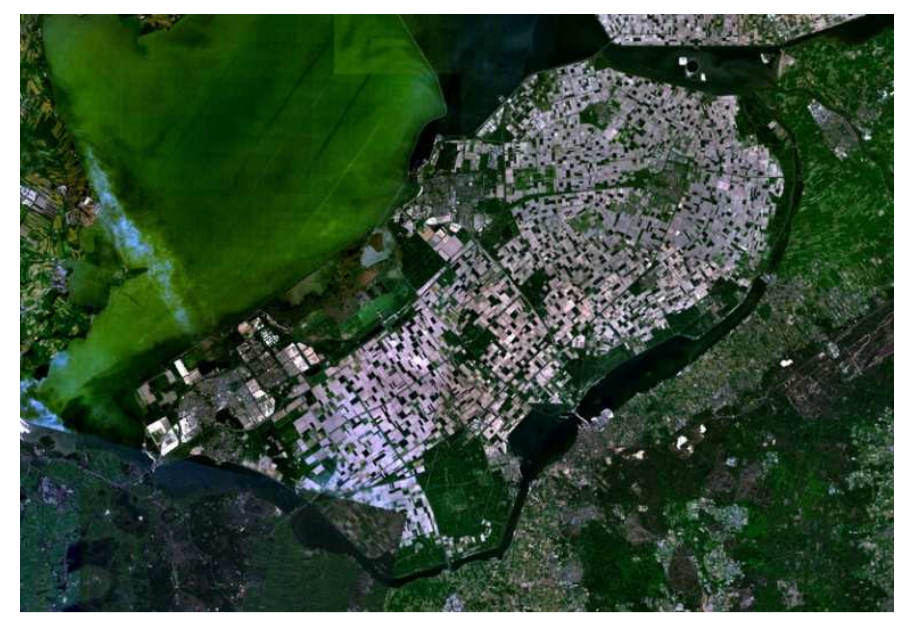

Figure 7. Flevopolder, Netherland, largest artificial island in the world [12]

The aspiration of the Dutch government to achieve efficient agricultural production in the period after WWII lead to formation of the national foundation - Foundation for Land Management SBL (later called Bureau for land Management BBL). This agency was formed within the Ministry of Agriculture and Fisheries in 1946 [3]. The main tasks of this agency were acquiring and managing land in rural areas, sale and distribution of land for various purposes.

The functioning of the land funds in the Netherlands is regulated by the following legislation:

- Land Consolidation Act, 1954.

- The rural area development Act, 1985. and

- Act on spatial structuring of the rural areas, 2005.

The land funds in Holland are financed from the government budget.

\subsection{Czech Republic}

Land fund in Czech Republic was established in 1991 by the Land Fund Act [20]. The task of the land fund is managing government owned property which includes agricultural land, forests, housing and other objects built in agricultural land. Land fund manages the property of former users government companies, identifies property owned by the state and concludes agreements on the lease of real estate that are under its supervision.
By establishing the land fund that managed the government owned land in the Czech Republic in 1991 the conditions were created for efficient implementation of land consolidation and efficient privatization of land [20]. The role of the land fund was in exchanging the government land with that of other owners and that way speed up the process of land consolidation.

In time problems appeared due to unsystematic sale of land which leads to land reserves being significantly reduced. The reasons behind that were the restitution that was done and the adoption of the Land Sales Act in 1999. According to that act, the long term lease of lend eventually lead to ownership while the price of government owned farmland was significantly reduced.

A problem such as this can lead to non transparent land transactions which can seriously jeopardize the principle of land funds operation full transparency and openness to public scrutiny.

Land fund in the Czech Republic is financed from own funds and it partially supports projects of land consolidation.

\subsection{Spanish province of Galicia}

The objectives of starting the land fund Xunta de Galicia in the Spanish province of Galicia were to regulate the use and exploitation of farming land plots, to prevent their abandoning and to make them available to those who need them for farming [13].

Galicia is a province where first land consolidations were done mid $20^{\text {th }}$ century. Till today, 280.000 ha was included in the land consolidation processes which makes up for less than $10 \%$ of the total area of the province. Land consolidation became a necessary instrument for further development of agricultural production. However, the deserted land was a huge obstacle to full implementation of land consolidation. Over $50 \%$ of the population inhabits $9 \%$ of the territory. Accordingly there is land in the rural part of the country for which there is no interest in farming. Therefore the fund was established primarily to solve this problem.

The land fund in Galicia was established in 2007 by the Ministry of Rural Affairs. Its establishment was preceded by the adoption of the Act 7/2007 on administrative and tax measures for the conservation of the utilised agricultural area and on the Land Bank of Galicia [10]. This act defined two different types of land policy measures:

- Measures that pertain to the creation of 
Galicia land fund, its management body and procedures for land transactions;

- Measures related to a penalty regime for those plots of land which are under conditions of abandonment [10].

Two components were developed for the functioning of the land fund (Fig. 8):

- BanTeGal - public company in charge of managing the land fund and
- Commission of Technical Prices and Valuation, which consists of representatives of various entities in Galicia (farming societies and unions, cadastre, etc). The task of this commission was defining the price for all operations implemented by BanTeGal.

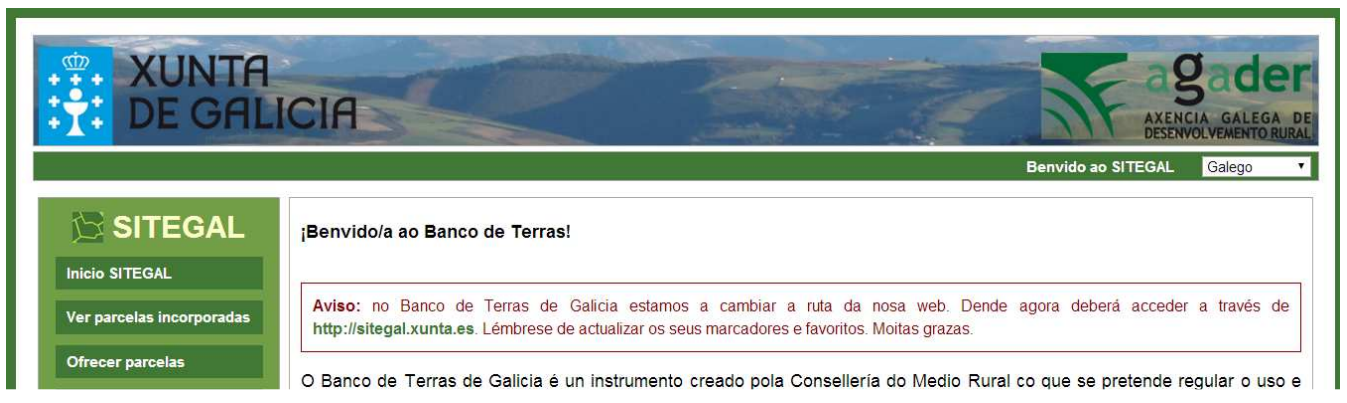

Figure 8. Printscreen of BanTeGal website [12]

One thing specific for the land fund of Galicia is that the ownership of the land included in the fund is maintained, which is an important distinction to other funds (Figure 9) [8].

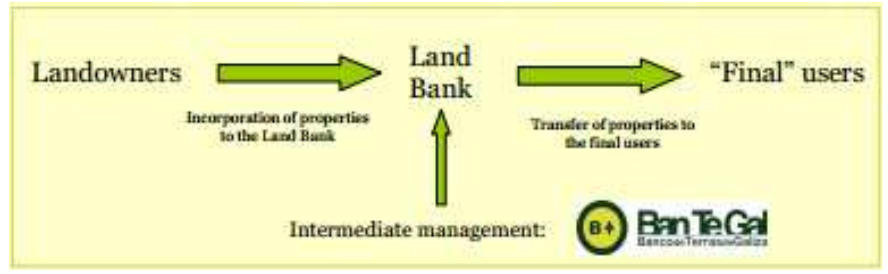

Figure 9. Movement of land within BanTeGal [9]

BanTeGal has the role of mediator between the land owner and the leasers and guarantees the conditions agreed between them. Apart from the supporting role in the implementation of land consolidation and role of mediator in the transactions, BanTeGal has an important role in spatial planning, development of new settlements and infrastructure, environmental protection and advancement of agricultural production.

Organizational structure of the Galicia land fund (Figure 10) is such that it includes Bangegal and Support institutions. Bantegal includes Central Office and 4 Provincial Delegations. Support Institutions encompasses around 60 offices at the local level. Management of the land fund is supported by the land information system SITEGAL.

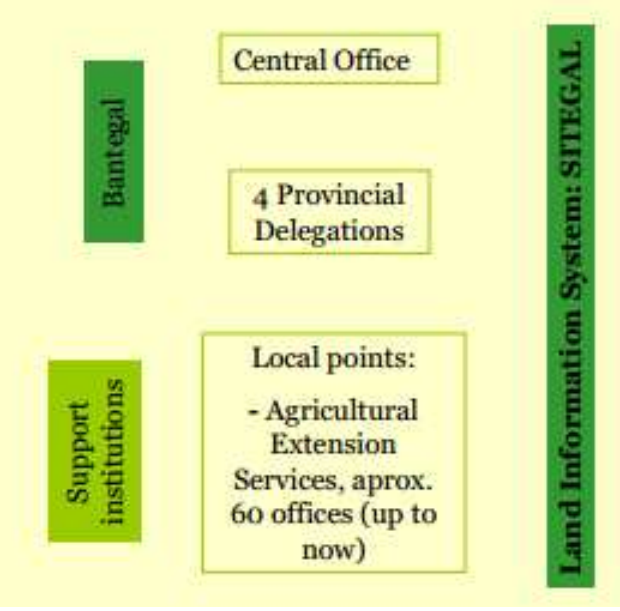

Figure 10. Ban Te Gal, management structure [9]

During the first three years of its existence, BanTeGal achieved the following:

- land bank included 8.726 parcels with area of 3.903 ha

- $12 \%$ of parcels rented along first 3 years

- total area rented is about 1100 ha, what corresponded to $39 \%$ of area included in bank

- improvement of structures of farms that have leased land from the fund [9].

In spite of successful business and achieved results, BanTeGal had to face some shortcomings:

- lack of coordination among various governmental bodies and organizations,

- technical difficulties in accessing the land information,

- finding usurped land, 
- extreme fragmentation of land,

- organizational problems,

- problems with the land leasing procedures, etc [9].

\section{Conclusions}

The examples of Denmark, Netherlands, Germanny, Czech Republic and Galicia can lead to conclusion that the land funds can vary significantly in terms of their goals, models, organizational structure, financing. Their common characteristic is that they are efficient means of land management.

The Republic of Serbia can expect significant deterioration of the ownership structure due to planned restitution and development of infrastructural objects. Also, Serbia has a similar problem to that of Galicia: it is estimated that it currently has around 300.000 ha of deserted land (not farmed or with unknown owners). For the purpose of improving efficiency of agricultural production it will be necessary to implement land management measures. The experiences of European countries, the ways they established land funds, can help us significantly improve the effects of land protection and consolidation.

According to the data available to the Ministry of Agriculture, the Republic of Serbia has over 900.000 ha of government owned land. It is estimated that after restitution around 250.000 ha of farming land will remain in government ownership.

Formation of the land fund in the Republic of Serbia will be a challenge for all those involved in land planning and development. This type of endeavour will require the change of legislation, spatial planning, organization of government administration, but the effects to land management would be enormous.

\section{Acknowledgement}

This paper was realized as a part of the project "Studying climate change and its influence on the environment: impacts, adaptation and mitigation" (43007) financed by the Ministry of Education and Science of the Republic of Serbia within the framework of integrated and interdisciplinary research for the period 2011-2014.

This paper is a part of the research realized during the preparation of the doctoral dissertation.

\section{References}

[1] „Komasacija u Srbiji - 1860-2003“, monography, Republic Geodetic Authority, Belgrade, 2003.

[2] Andersen, N. M.: Land banking and land fund schemes in Denmark, FAO International Workshop on Land Banking/Land Funds as an Instrument for Improved Land Management for CEEC and CIS, Tonder, Denmark, 2004.

[3]Berg van de, R., Revilla E. L., Manken, M., Verbeek, I.: Land banking principle, Wareningen University, Land Use Planning Group, 2005.

[4] Blaabjerg, E.: The Danish experience with Land Banking, FAO Regional Workshop on Land Tenure and Land Consolidation - Land Banks and Impact Assessment, Prague, Czech Republic, 2008.

[5] Bogdanović, B.: “Agrarne operacije", Faculty of Civil Engineering, Belgrade, 1989.

[6] Conley, T. L.: „Banking on Vacant Land: An Assessment of the Cincinati Land Reutilization Program “, master thesis, University of Cincinnati, 2008.

[7]Damen, J.: Land banking in The Netherlands in the context of land consolidation, FAO International Workshop on Land Banking/Land Funds as an Instrument for Improved Land Management for CEEC and CIS, Tonder, Denmark, 2004.

[8] Diaz, M., Zolle, C., Ónega, O., Coimbra, E.: Operative aspects of Land Bank of Galicia. Monitoring activities, FAO Regional Workshop on Land Tenure and Land Consolidation - Land Banks and Impact Assessment, Prague, Czech Republic, 2008.

[9]Fernández, C. Z.: Land bank of Galicia (Spain): main success points and difficulties after 3 years of working, FAO Workshop on Land Tenure \& Land Consolidation - Land Banking and Public Land Management, Prague, Czech Republic, 2010.

[10] Fernandez. C. Z.: Land fragmentation and Land Banking in Galicia, Regional Workshop on Land Tenure and Land Consolidation - Land Banks and Impact Assessment, Prague, Czech Republic, 2008.

[11] http://de.wikipedia.org/wiki/BVVG_Bodenverw ertungs- und -verwaltungs $\mathrm{GmbH}, 18.3 .2014$.

[12] http://en.wikipedia.org/wiki/File:Satellite_image _of_Flevopolder,_Netherlands_(5.48E_52.43N).png, 18.3.2014.

[13] http://sitegal.xunta.es/sitegal/SetLocale.do;jsessi onid=AEC4429FDF67158CCC538681E09B00E2, 18.3.2014.

[14] http://www.fao.org/europe/meetings-and-events2010/events-2009/landcons5/en/, 18.3.2014.

[15] http://www.fao.org/europe/meetings-and-events2010/land2004/en/, 18.3.2014.

[16] http://www.fao.org/europe/meetings-and-events2010/land2008/en/, 18.3.2014.

[17] http://www.fao.org/europe/meetings-and-events- 
2010/lblc2010/en/, 18.3.2014.

[18] http://www.fao.org/europe/meetings-and-events2010/prague2010/en/, 18.3.2014.

[19] http://www.fao.org/europe/meetings-and-events2012/4th-landnet/en/, 18.3.2014.

[20] http://www.fao.org/fileadmin/user_upload/Euro pe/documents/Events 2004/Land2004/Czech paper. pdf, 18.3.2014.

[21] https://www.bvvg.de/INTERNET/internet.nsf/H TML/START, 18.3.2014.

[22] Kreese, S., Dells, K., Arnim, H. E.: The Role of Land Banks/Land Funds in the Privatization Process, FAO International Workshop on Land Banking/Land Funds as an Instrument for Improved Land Management for CEEC and CIS, Tonder, Denmark, 2004.

[23] Marošan, S.: "Definisanje vrednosnog okvira za ocenu zemljišnih komasacionih sistema", dissertation, Faculty of Civil Engineering, Belgrade, 2013.

[24] Milićević, D., Marošan, S., Božić, B.:THE HISTORY OF LAND CONSOLIDATION IN SERBIA, The First International Symposium of Agricultural Engineering, University of Belgrade, Faculty of Agriculture, pp. VI-15 - VI-23 (

http://www.isae.agrif.bg.ac.rs/index_files/ISAE2013\%20Proceedings.pdf, 16.12.2013.)

[25] Sebestyén, R.: The National Land Fund, FAO International Workshop on Land Banking/Land Funds as an Instrument for Improved Land Management for CEEC and CIS, Tonder, Denmark, 2004.

[26] Thomas, J.: The Status of Land Development and Land Consolidation in Europe - 2011 - a cross section analysis, FAO international LANDNET workshop on Land Market Development and Land Consolidation, Budapest, 2012 